\title{
Using fallout radionuclides to investigate recent overbank sedimentation rates on river floodplains: an overview
}

\author{
VALENTIN GOLOSOV ${ }^{1,2}$ \& DESMOND E. WALLING \\ 1 Institute of Ecology and Geography, Kazan Federal University, Kremlevskaya st., Kazan, Russia \\ gollossov@rambler.ru \\ 2 Faculty of Geography, Lomonosov Moscow State University, Leninskie Gory, Moscow Russia \\ 3 Geography, College of Life and Environmental Sciences, University of Exeter, UK.
}

\begin{abstract}
Information on rates of overbank sedimentation on river floodplains is needed for a variety of purposes. Use of ${ }^{137} \mathrm{Cs}$ and ${ }^{210} \mathrm{~Pb}_{\text {ex }}$ measurements provides an effective means of estimating medium-term floodplain sedimentation rates and that approach has now been successfully used in many areas of the world. This contribution reviews the use of ${ }^{137} \mathrm{Cs}$ and ${ }^{210} \mathrm{~Pb}_{\mathrm{ex}}$ measurements in floodplain sedimentation investigations and discusses some of the important sampling requirements and key issues associated with interpreting the measurements, and subsequently deriving reliable estimates of sedimentation rates. The potential use of other radionuclides, including ${ }^{241} \mathrm{Am},{ }^{238,239+240} \mathrm{Pu}$, and ${ }^{7} \mathrm{Be}$ is considered, and the advantages of using two or more radionuclides, in combination, is highlighted.
\end{abstract}

Key words overbank sedimentation rates; river floodplain; fallout radionuclide; ${ }^{137} \mathrm{Cs} ;{ }^{210} \mathrm{~Pb}$; ${ }^{7} \mathrm{Be} ;{ }^{239+240} \mathrm{Pu}$; geochronology; Chernobyl fallout; bomb derived-fallout

\section{INTRODUCTION}

Recent years have seen a growing interest in determining the rates of overbank sedimentation on river floodplains. This interest reflects, firstly, a desire to develop an improved understanding of floodplain evolution and, secondly, increasing recognition of the important role of river floodplains as fine-sediment sinks within the fluvial system. Overbank sedimentation rates on river floodplains provide a key indicator of the intensity of sediment and sediment-associated pollutant redistribution in river basins and the efficiency of sediment delivery. A variety of techniques have been employed for documenting overbank sedimentation rates, including sediment traps, reduction in sediment load through a reach, and the use of marker horizons. However use of the fallout radionuclides (FRNs) caesium-137 $\left({ }^{137} \mathrm{Cs}\right)$ (bomb-derived and/or Chernobyl-derived) and excess lead-210 $\left({ }^{210} \mathrm{~Pb}_{\mathrm{ex}}\right)$ (see He \& Walling, 1996; Walling \& He, 1997) has been shown to provide a particularly effective means of documenting recent medium-term overbank sedimentation rates. The use of ${ }^{137} \mathrm{Cs}$ and ${ }^{210} \mathrm{~Pb}_{\text {ex }}$ to estimate sedimentation rates involves different principles. In the case of ${ }^{137} \mathrm{Cs}$, a man-made radionuclide, the chronology is provided by the position of the radiocaesium peak or peaks in the sediment profile, which can be attributed to the period of peak bomb fallout in 1963/4 or the occurrence of Chernobyl fallout in 1986 . Unlike ${ }^{137} \mathrm{Cs}^{2}{ }^{210} \mathrm{~Pb}_{\text {ex }}$ is a natural or geogenic radionuclide and its fallout is essentially constant from year to year. Attention is therefore directed to the downcore reduction in ${ }^{210} \mathrm{~Pb}_{\mathrm{ex}}$ activity, which in turn reflects the sedimentation rate over the past $c .100$ years. ${ }^{210} \mathrm{~Pb}$ has a half-life of 22.3 years and, where the sedimentation rate is relatively rapid, the ${ }^{210} \mathrm{~Pb}_{\text {ex }}$ activity will decrease relatively slowly with depth. However, where the sedimentation rate is relatively low, the ${ }^{210} \mathrm{~Pb}_{\text {ex }}$ activity will decline more rapidly with depth. The two FRNs have now been successfully used for documenting floodplain sedimentation rates in many areas of the world (e.g. Terry et al., 2002, 2011; Ritchie et al., 2004, Hughes et al., 2009; Locas et al., 2010). The use of ${ }^{137} \mathrm{Cs}$ and ${ }^{210} \mathrm{~Pb}_{\mathrm{ex}}$ measurements in combination has proved particularly useful in areas of Europe affected by Chernobyl fallout, because it is frequently possible to determine sedimentation rates for three or more time intervals (Lair et al., 2010; Du \& Walling, 2012; Golosov et al., 2013). The resulting information on sediment chronology provided by FRN measurements can also be used for reconstructing the history of industrial and agricultural pollution in upstream river basins (e.g. Walling et al., 2003; Macklin et al., 2006; Ciszewski \& Czajka, 2009; Locas et al., 2010; Golosov et al., 2012).

Despite the important advantages of FRNs for establishing overbank sedimentation rates and dating sediment deposits, it is important to recognise the possible limitations of the technique, as 
well as the sampling and analytical requirements which need to be carefully considered when documenting and interpreting radionuclide depth distributions on floodplains. For example, if sedimentation rates are relatively low, there may be a need to take into account the possible downward displacement of the ${ }^{137} \mathrm{Cs}$ peak when calculating the mean annual sedimentation rate. Recently published studies indicate that the requirements for the successful application of FRN tracer techniques for documenting overbank sedimentation rates on river floodplains are unfortunately sometimes given little attention, leading to unreliable results or incorrect interpretations. The aim of this paper is to discuss further the potential and the limitations of FRNs for investigating overbank sedimentation rates on river floodplains. The potential application of other FRNs (including ${ }^{238} \mathrm{Pu},{ }^{239} \mathrm{Pu} /{ }^{240} \mathrm{Pu}$ and ${ }^{7} \mathrm{Be}$ ) in floodplain sedimentation investigations is also discussed.

\section{SAMPLING PROGRAMME DESIGN, SAMPLING PROCEDURES AND SEDIMENT ANALYSIS}

A well-designed sampling programme is the key to the successful application of FRN measurements for documenting floodplain deposition. There are two basic requirements that need to be taken into account in most, if not all, investigations. Firstly, the local reference inventory of the FRN used should be established. This is important for interpreting the inventories measured at sampling points on the floodplain. Secondly, depth incremental sampling should be undertaken at one or more sampling points to establish the depth distribution of the FRN. This information is required to ensure that results and interpretations are consistent with the expected behaviour of the FRN. If, as will often be the case, existing information on the local reference inventory is not available, it should be established by sampling a suitable reference site. River terraces or flat undisturbed interfluve areas generally will provide suitable reference sites. When selecting sampling points on a floodplain, preference should be given to open areas without trees or shrubs, and locations where soils are expected to be undisturbed. Tree and shrub canopies are likely to influence the spatial homogeneity of fallout receipt and thus the background reference inventory. Where floodplain soils are cultivated or degraded by overgrazing, surface material can be mobilised and removed by overbank flows, reducing the inventory. In many recently published studies involving the use of ${ }^{137} \mathrm{Cs}$ measurements to document floodplain sedimentation rates, little account has been taken of some of these requirements (Table 1).

Table 1 Recent rates of overbank floodplain sedimentation estimated using the ${ }^{137} \mathrm{Cs}$ technique.

\begin{tabular}{|c|c|c|c|c|c|c|}
\hline River & Country & $\begin{array}{l}\text { Reference value } \\
\text { for }{ }^{137} \mathrm{Cs} \text { fallout }\end{array}$ & $\begin{array}{l}\text { Mean } \\
\text { sedimen- } \\
\text { tation rate } \\
\left(\mathrm{cm} \text { year }^{-1}\right)\end{array}$ & $\begin{array}{l}\text { Time- } \\
\text { scale } \\
\left(\text { year }^{-1}\right)\end{array}$ & Reference & Remarks \\
\hline Morava River & $\begin{array}{l}\text { Czech } \\
\text { Republic }\end{array}$ & Not determined & 0.6 & 20 & Kadlec et al., 2009 & Only Chernobyl (?) peak \\
\hline $\begin{array}{l}\text { Wainimala } \\
\text { River }\end{array}$ & Fiji & Not determined & 3.2 & 40 & Terry et al., 2002 & $\begin{array}{l}\text { Foothills, river terrace } \\
\text { (?) }\end{array}$ \\
\hline Falefa River & Samoa & Not determined & 4.0 & 40 & Terry et al., 2006 & Only one section \\
\hline Stemple Creek & USA & Not determined & 0.85 & 40 & Ritchie et al., 2004 & $\begin{array}{l}\text { Mean for different } \\
\text { floodplain levels }\end{array}$ \\
\hline Theresa Creek & Australia & $\begin{array}{l}\text { Available, but } \\
15 \mathrm{~km} \text { from } \\
\text { sampling site }\end{array}$ & 0.13 & 50 & Hughes et al., 2009 & $\begin{array}{l}\text { Mean value for few } \\
\text { sections }\end{array}$ \\
\hline $\begin{array}{l}\text { West Fork } \\
\text { Black's Fork } \\
\text { River }\end{array}$ & USA & Not determined & 0.45 & 40 & Carson, 2006 & $\begin{array}{l}\text { Mean value for few } \\
\text { locations }\end{array}$ \\
\hline $\begin{array}{l}\text { Upper } \\
\text { Mississippi }\end{array}$ & USA & Not determined & 1.0 & 40 & Benedetti, 2003 & $\begin{array}{l}\text { Mean value for two } \\
\text { cross-sections }\end{array}$ \\
\hline Kuchoro River & Japan & Not determined & 1.3 & 40 & $\begin{array}{l}\text { Mizugaki et al., } \\
2006\end{array}$ & $\begin{array}{l}\text { Mean value for few } \\
\text { sections }\end{array}$ \\
\hline Severn River & UK & Available & $\begin{array}{l}0.7 \\
1.38\end{array}$ & $\begin{array}{l}25 \\
45\end{array}$ & Du \& Walling, 2012 & $\begin{array}{l}\text { Since } 1986 \\
\text { For period } 1963-1986\end{array}$ \\
\hline
\end{tabular}


Sampling design will vary depending on study goals and available analytical resources. Sampling may involve collections along transects across the floodplain at different distances from the river channel (Ritchie et al., 2004; Mizugaki et al., 2006); at individual points along the river reach (Benedetti, 2003; Carson, 2006; Golosov et al., 2010), including tributaries (Hughes et al., 2009; Du \& Walling, 2012); or grid-based systematic sampling across the floodplain, in order to include different morphological elements or different floodplain levels (Walling \& He, 1998; Belyaev et al., 2013). When only one sampling point is used to establish the depth distribution of an FRN, it is important to demonstrate why this particular point can be expected to provide representative information on overbank sedimentation rates for the river floodplain under investigation. It is well-known that in mountain areas in particular, maximum deposition often is observed in the reaches where river channel gradient decreases considerably, for example, in the foothills. If the sampling point is located within such a reach, it is likely to document extremely high overbank sedimentation rates (e.g. Terry et al., 2002, 2006), which are only found in such locations and hence, may not be representative of the entire area.

Depth incremental sampling of floodplain sediment can be undertaken using two approaches: directly in the field from a fixed area using an appropriate depth increment (e.g. 1-5 cm) (Kadlec et al., 2009; Golosov et al., 2010; Belyaev et al., 2013) or using a coring device to collect a sediment core, which subsequently is sectioned into the required depth increments (e.g. 1-2 cm) in the laboratory (Walling et al., 1998; Walling \& He, 1998). Selection of an appropriate diameter for the core should reflect the mass of sample required from a given depth increment for a reliable analysis, as well as the greater spatial representativeness associated with a larger diameter core. It is necessary to recognize that where the depth distribution of an FRN is established using a core, the depth distribution may be influenced by compaction, particularly where this varies with depth due to variations in sediment properties. The compaction issue is frequently ignored and is likely to lead to errors in the estimation of sedimentation rates, particularly with deep sediment profiles. Such problems may be avoided, if depth is represented as mass-depth $\left(\mathrm{g} \mathrm{m}^{-2}\right)$ when plotting the down-profile distribution (Fig. 1).
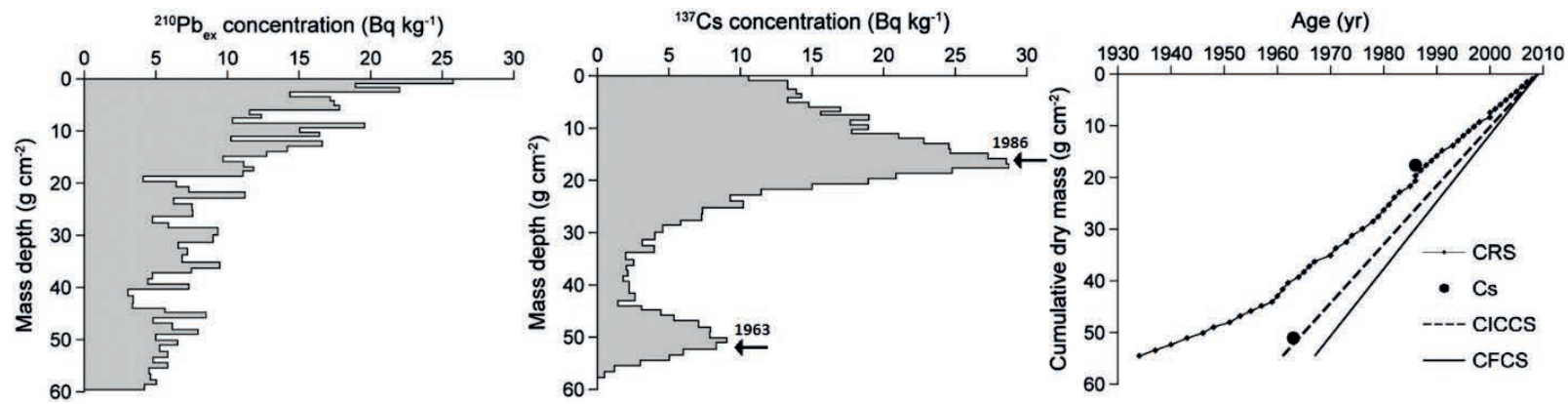

Fig. 1 The ${ }^{210} \mathrm{~Pb}_{\mathrm{ex}}$ and ${ }^{137} \mathrm{Cs}$ profiles associated with a sediment core collected from the floodplain of the River Severn, UK, and a comparison of the age-depth relationships derived from the ${ }^{210} \mathrm{~Pb}_{\mathrm{ex}}$ data using the CRS, CICCS and CFCS models and from the ${ }^{137} \mathrm{Cs}$ depth distribution (based on Du \& Walling, 2012).

The bulk core sampling approach, permits improved representation of the spatial variation of sedimentation rates across a study site, by estimating the sedimentation rate from measurements of the total inventory associated with individual sampling sites (Walling \& He, 1997). However, it still involves depth incremental sampling since it is based on extrapolating the sedimentation rate estimated for a master sampling point from the ${ }^{137} \mathrm{Cs}$ depth distribution across a larger area. The following function is used to estimate the sedimentation rate at a bulk core sampling point:

$$
R_{b}=R_{m} \times \frac{A_{b}-A_{r e f}}{A_{m}-A_{r e f}}
$$

where $R_{b}$ is the estimate of sedimentation rate for the bulk core $\left(\mathrm{kg} \mathrm{m}^{-2}\right.$ year-1 $) ; R_{m}$ is the 
sedimentation rate estimated for the master sampling point from the ${ }^{137} \mathrm{Cs}$ depth distribution $\left(\mathrm{kg} \mathrm{m}^{-2}\right.$ year $\left.{ }^{-1}\right) ; A_{b}$ is the ${ }^{137} \mathrm{Cs}$ inventory for the bulk core $\left(\mathrm{Bq} \mathrm{m}{ }^{-2}\right) ; A_{m}$ is the ${ }^{137} \mathrm{Cs}$ inventory for the master sampling point $\left(\mathrm{Bq} \mathrm{m}^{-2}\right)$, and $A_{\text {ref }}$ is the ${ }^{137} \mathrm{Cs}$ reference inventory for the study site $\left(\mathrm{Bq} \mathrm{m}^{-2}\right)$.

Recently both bomb-derived and Chernobyl ${ }^{137} \mathrm{Cs}$ have been used in combination with ${ }^{210} \mathrm{~Pb}_{\text {ex }}$ for reconstructing the geochronology of floodplain sediments, and the combined use of FRNs clearly offers considerable potential. Other FRNs also have been used. ${ }^{239+240} \mathrm{Pu}$ associated with bomb fallout has been used in a number of studies in the Southern Hemisphere as an alternative to ${ }^{137} \mathrm{Cs}$, because the peak in ${ }^{137} \mathrm{Cs}$ activity associated with maximum fallout levels in 1964 is increasingly difficult to detect due to radioactive decay. This situation will become increasingly common in the future. $\mathrm{Pu}$ isotopes can provide dated time horizons associated with the ${ }^{239+240} \mathrm{Pu}$ fallout peak in 1964 , and a peak in the ${ }^{238} \mathrm{Pu} /{ }^{239+240} \mathrm{Pu}$ ratio can be dated to 1968 as it corresponds with the disintegration of the SNAP-9A satellite (Leslie \& Hancock, 2008). Measurements of ${ }^{241} \mathrm{Am}$ concentrations in floodplain sediment also permit the peaks related to Chernobyl and bombderived ${ }^{137} \mathrm{Cs}$ fallout to be distinguished, because the ${ }^{241} \mathrm{Am}$ is primarily associated with bombderived fallout (Bunzl et al., 1994). Blake et al. (2002) also have reported the successful use of ${ }^{7} \mathrm{Be}$, a naturally occurring short-lived cosmogenic radionuclide (half-life 53 days), to estimate short-term (event-based) floodplain sedimentation. However, to date there have been few other attempts to use this FRN, despite its obvious potential for documenting sedimentation associated with individual events. Measurement precision associated with the various radionuclides depends on the accuracy of the measuring equipment and methods employed. Most measurements are made using gamma spectrometry, but $\mathrm{Pu}$ isotopes are measured using alpha spectrometry or mass spectrometry (AMS), and both gamma and alpha spectrometry can be used for ${ }^{210} \mathrm{~Pb}$.

Where significant differences in sediment grain-size composition occur across a floodplain, and the bulk core approach is being used to maximize the number of point samples, there is a need to take this into account when estimating sedimentation rates for either the section or reference cores to the bulk cores. Walling \& He (1997) proposed the following correction for ${ }^{137} \mathrm{Cs}$ measurements:

$$
R^{\prime}=R_{0}^{\prime} \times \frac{I_{e x}}{I_{e x, 0}}\left(\frac{S_{d, 0}}{S_{d}}\right)^{v}
$$

where $R^{\prime}$ and $R_{0}^{\prime}$ represent the sedimentation rates at the measurement point (bulk core) and at the reference point (sectioned core), respectively $\left(\mathrm{kg} \mathrm{m}^{-2}\right.$ year $\left.{ }^{-1}\right) ; S_{d, 0}$ and $S_{d}$ represent the specific surface area of surface sediment from the reference point (sectioned core) and the measurement point, respectively $\left(\mathrm{m}^{2} \mathrm{~g}^{-1}\right) ; I_{e x, o}$ and $I_{e x}$ represent the values of excess inventory relative to the local reference inventory at the reference point (sectioned core) and at the measurement point, respectively $\left(\mathrm{Bq} \mathrm{m}^{-2}\right)$; and $v$ is a constant reflecting the relationship between ${ }^{137} \mathrm{Cs}$ concentration and specific surface area (range $0.65-0.7$ ).

\section{PRESENTATION AND INTERPRETATION OF RESULTS}

Depending on the sampling location, the ${ }^{137} \mathrm{Cs}$ depth distribution measured in floodplain sediments can be characterized by zero, one, or several peaks, in response to a range of causes. The lack of any ${ }^{137} \mathrm{Cs}$ peak can reflect a number of reasons, including, insufficient sampling depth, the location of the sampling point in a section of recently created floodplain which has not received ${ }^{137} \mathrm{Cs}$ fallout, erosion of the floodplain surface, or removal of the sediment containing ${ }^{137} \mathrm{Cs}$, for example, by drifting ice during spring flooding (Belyaev et al., 2011), and cultivation of the floodplain which will redistribute the ${ }^{137} \mathrm{Cs}$ uniformly throughout the plough depth. In areas not affected by fallout from Chenobyl, Fukushima, or other local sources, two peaks (1959/60 and 1963/4) of bomb-derived ${ }^{137} \mathrm{Cs}$ activity associated with periods of maximum ${ }^{137} \mathrm{Cs}$ fallout during nuclear bomb testing in the open atmosphere can sometimes be identified. However, in most cases it is difficult to distinguish the 1959 peak because it is of a smaller magnitude, and may be blurred by the vertical migration of ${ }^{137} \mathrm{Cs}$ from the 1963 peak. Macklin et al. (2006) attempted to identify a ${ }^{137} \mathrm{Cs}$ peak in a sediment profile corresponding to 1954 , but the fallout record provides no evidence 
of such a peak. In many studies, the depth at which ${ }^{137} \mathrm{Cs}$ first appears in the profile has been dated to 1954 , representing the beginning of significant bomb fallout. This chronology has then been used to estimate sedimentation rates for the period 1954 to 1963 , or from 1954 to the time of sampling (e.g. Knox, 2006). However, this approach is flawed, since in most environments the depth reached by the 'tail' of the ${ }^{137} \mathrm{Cs}$ depth distribution will be influenced by downward migration. This results in the overestimation of sedimentation rates. As a result, many studies have erroneously reported that the years 1954-1963 were characterized by unusually high sedimentation rates. In areas affected by Chernobyl fallout (only part of Europe) it is generally possible to identify both bomb-derived and Chernobyl-derived peaks (Fig. 2).
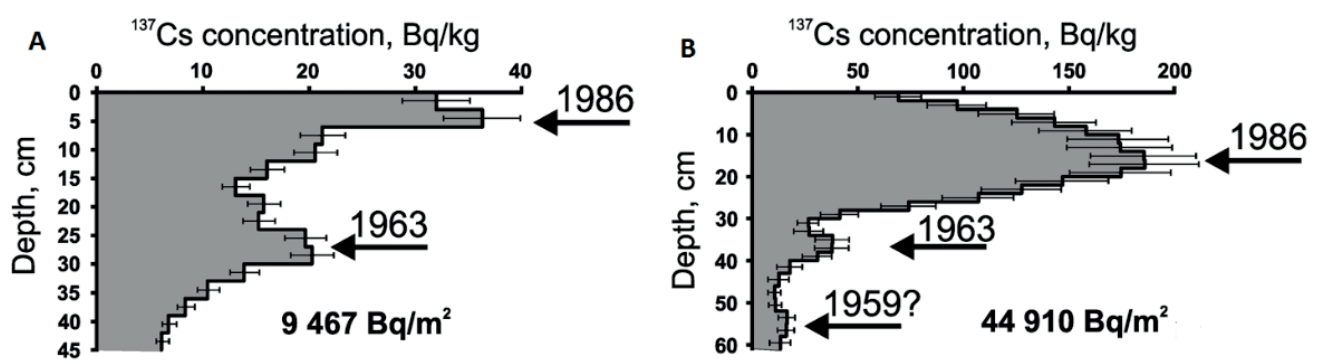

Fig. $2{ }^{137} \mathrm{Cs}$ profiles associated with sediment cores collected from the floodplains of the Zusha River (A) and the Turdei River (B) in Russia. (based on Golosov et al., 2013).

Detailed maps of Chernobyl ${ }^{137} \mathrm{Cs}$ fallout and information on the magnitude of ${ }^{137} \mathrm{Cs}$ bomb fallout are available for most areas of Europe, and the use of such data can assist in the correct interpretation of the Chernobyl peak in ${ }^{137} \mathrm{Cs}$ depth distributions in floodplain sediments. However, as indicated above, additional measurements of ${ }^{241} \mathrm{Am}$ activity in the sediment can provide another basis for distinguishing the two peaks. Although evidence of Chernobyl-derived ${ }^{137} \mathrm{Cs}$ fallout has been reported for sedimentation sites outside Europe (e.g. Lu \& Higgitt, 2001; Yan et al., 2002; Mizugaki et al., 2006) such claims must be treated with considerable caution, since fallout levels outside Europe were very low. In areas where the fallout of Chernobyl-derived ${ }^{137} \mathrm{Cs}$ was very high, it is generally only possible to identify the 1986 peak, because of the downward migration of highly contaminated particles (Golosov et al., 2013).

As indicated above, it is sometimes difficult to use bomb-derived ${ }^{137} \mathrm{Cs}$ in the Southern Hemisphere for the estimation of sedimentation rates, because the bomb-derived ${ }^{137} \mathrm{Cs}$ peak (1964) cannot be clearly identified due to low activity. Several studies have shown that ${ }^{239+240} \mathrm{Pu}$ can replace bomb-derived ${ }^{137} \mathrm{Cs}$ (Leslie \& Hancock, 2008; Amos et al., 2009); as a result, it will be possible to use this FRN for this purpose far into the future due to its extended half-life (Fig. 3).

Estimation of floodplain sedimentation rates using ${ }^{210} \mathrm{~Pb}_{\text {ex }}$ depth distributions documented for individual study sites requires the use of a model to establish the age-depth relationship for a downcore profile. Four ${ }^{210} \mathrm{~Pb}$ dating models are used fairly commonly. Three of them were initially developed for lake sediments, namely, the Constant Flux: Constant Sedimentation (CFCS) model, the Constant Initial Concentration (CIC) model, and the Constant Rate of Supply (CRS) model. The Constant Initial Concentration and Constant Sedimentation rate (CICCS) model was developed specifically for floodplain sediments and episodic sedimentation (see He \& Walling, 1996; Du \& Walling, 2012) (Fig. 1).

Use of ${ }^{210} \mathrm{~Pb}_{\text {ex }}$ and ${ }^{137} \mathrm{Cs}$ in combination permits changes in overbank sedimentation rates to be documented over the past 100 years or so (He \& Walling, 1996; Du \& Walling, 2012). The advantages of this combined use of both radionuclides include the potential for using ${ }^{137} \mathrm{Cs}$ to validate the different models available for interpreting ${ }^{210} \mathrm{~Pb}_{\text {ex }}$ measurements (Fig. 1). Use of the ${ }^{210} \mathrm{~Pb}_{\text {ex }}$ technique in isolation can result in highly uncertain estimates of floodplain sedimentation rates (Saint-Laurent et al., 2010). In some cases, incorrect interpretation of ${ }^{137} \mathrm{Cs}$ depth profiles and incorrect application of ${ }^{210} \mathrm{~Pb}_{\text {ex }}$ measurements also can result in erroneous conclusions regarding sedimentation rates (Humphries et al., 2010). It should be noted that chronologies based on ${ }^{210} \mathrm{~Pb}_{\text {ex }}$ measurements are more likely to be correct where sediment accumulation rates are not highly 


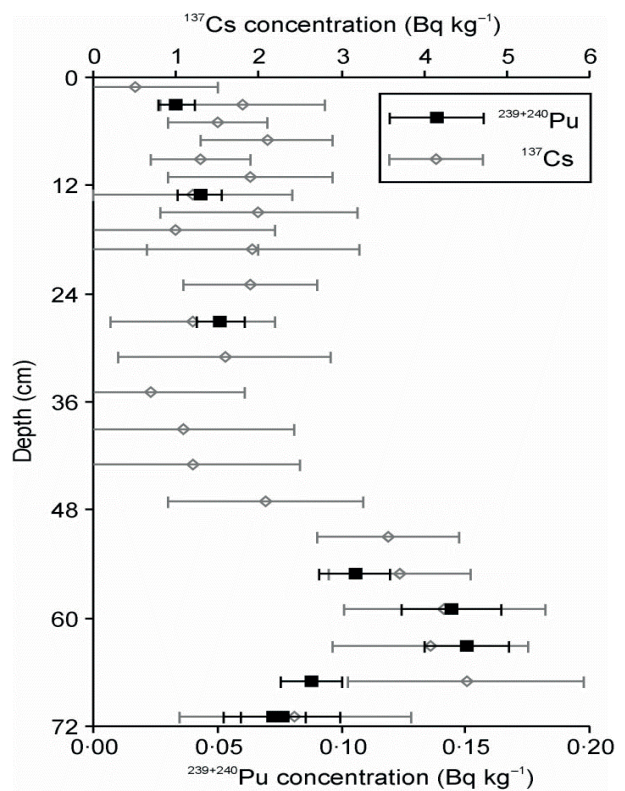

Fig. 3 Comparison of the depth profiles of ${ }^{239+240} \mathrm{Pu}$ and ${ }^{137} \mathrm{Cs}$ concentrations associated with a core collected from the floodplain of the Fitzroy River, northeastern Australia. Measurement uncertainty at the 95 per cent confidence limit is indicated (based on Amos et al., 2009).

variable through time, because of the assumptions used in the modelling of the decay profiles. Where the timescale investigated exceeds 50-60 years, the use of additional dating methods (OSL, ${ }^{14} \mathrm{C}$ ) in combination with ${ }^{210} \mathrm{~Pb}_{\text {ex }}$ geochronology is recommended to ensure reliable results (Bostock et al., 2007; Saint-Laurent et al., 2010).

\section{PERSPECTIVES}

The use of FRNs for documenting overbank sedimentation rates, and reconstructing the chronology of floodplain evolution during periods of intensive industrial and agricultural pressure on fluvial systems can generate a greatly improved understanding of the evolution of floodplains and river valley bottoms, especially with respect to the accumulation and subsequent redistribution of sediment-associated pollutants. The advantages of such an approach have been clearly demonstrated for several river basins (Ciszewski \& Czajka, 2009; Golosov et al., 2012). It is suggested that scope exists to expand such work, as individual case studies, by selecting a number of relatively small river basins within the area of Europe affected by Chernobyl fallout, in conjunction with well-documented land-use histories for the second half of the 20th century, good meteorological and river flow data, and some sources of point and diffuse contamination. Documentation of the changes in floodplain sedimentation rates during this relatively short time interval could provide valuable evidence of the impact of climate variations and land-use change on catchment sediment budgets, sediment delivery processes, and the fate of sediment-associated contaminants within the fluvial system. Such a study could afford a unique opportunity for European scientists to acquire directly comparable and integrated data related to sediment redistribution dynamics for different landscape and climatic zones, under different levels of anthropogenic pressure, and with different intensities and types of pollution.

Acknowledgements This work was partly funded by the RFBR (projects 13-05-00162 and 14-0592105 YAF) and the President of the Russian Federation support program for leading Scientific Schools (project NS-1010.2014.5).

\section{REFERENCES}

Amos, K.A., et al. (2009) The application of caesium-137 measurements to investigate floodplain deposition in a large semiarid catchment in Queensland, Australia: low-fallout environment. Earth Surf. Process. Landforms 34, 515-529. 
Belyaev, V. R., et al. (2013) Using Chernobyl-derived ${ }^{137} \mathrm{Cs}$ to document recent sediment deposition rates on the River Plava floodplain (Central European Russia). Hydrol. Processes 27, 781-794.

Belyaev, V.R., et al. (2011) Assessment of overbank sedimentation rates and associated pollutant transport within the Severnaya Dvina River Basin. Geography Environment Sustainability 4, 68-84.

Benedetti, M.M. (2003) Controls on overbank deposition in the Upper Mississippi River. Geomorphology 56, $271-290$.

Blake, W.H., Walling, D.E. \& He, Q. (2002) Using cosmogenic Beryllium-7 as a tracer in sediment budget investigations. Geografiska Annaler 84A, 89-102.

Bostock, H.C., et al. (2007) Holocene and modern sediment storage in the subtropical macrotidal Fitzroy River estuary, Southeast Queensland, Australia. Sedimentary Geology 201, 321-340

Bunzl, K., Kracke, W. \& Schimmack, W. (1994) Residence times of fallout ${ }^{239,240} \mathrm{Pu},{ }^{238} \mathrm{Pu},{ }^{241} \mathrm{Am}$ and ${ }^{137} \mathrm{Cs}$ in the upper horizons of an Undisturbed grassland soil. J. Environ. Radioactivity 22, 11-27.

Carson, E.C. (2006) Hydrologic modeling of flood conveyance and impacts of historic overbank sedimentation on West Fork Black's Fork, Uinta Mountains, northeastern Utah, USA. Geomorphology 75, 368-383.

Ciszewski, D. \& Czajka, A. (2009) Sediment accumulation on alluvial plains of the heavily impacted river reaches: upper Vistula and Odra, southern Poland. Przeglad Geologiczny 57, 576-583.

Du, P. \& Walling, D.E. (2012) Using ${ }^{210} \mathrm{~Pb}$ measurements to estimate sedimentation rates on river floodplains. J. Environ. Radioactivity 103, 59-75.

Golosov, V.N., Belyaev, V.R. \& Markelov M.V. (2013) Application of Chernobyl-derived ${ }^{137}$ Cs fallout for sediment redistribution studies: lessons from European Russia. Hydrol. Processes 27, 807-821.

Golosov, V.N., et al. (2010) Overbank sedimentation rates on the flood plains of small rivers in Central European Russia. In: Sediment Dynamics for a Changing Future (ed. by Banasik, K. et al.) (Proceedings of a Symposium held in Warsaw, Poland, June 2010), 129-136, IAHS Publ. 337. IAHS Press, Wallingford, UK.

Golosov, V. N., et al. (2012) Redistribution of sediment and sediment-associated contaminants in the River Chern basin during the last 50 years. In: Erosion and Sediment Yields in the Changing Environment (ed. by Collins, A. et al.) (Proceedings of a Symposium held in Chengdu, China, October 2012), 12-19. IAHS Publ. 356. IAHS Press, Wallingford, UK.

He, Q. \& Walling, D.E. (1996) Use of fallout Pb-210 measurements to investigate longer-term rates and patterns of overbank sediment deposition on the floodplains of lowland rivers. Earth Surf. Process. Landforms 21, 141-154.

Hughes, A.O., et al. (2009) Determining floodplain sedimentation rates using ${ }^{137} \mathrm{Cs}$ in a low fallout environment dominated by channel- and cultivation-derived sediment inputs, central Queensland, Australia. J. Environ. Radioactivity 100, 858-865.

Humphries, M.S., et al. (2010) ${ }^{137} \mathrm{Cs}$ and ${ }^{210} \mathrm{~Pb}$ derived sediment accumulation rates and their role in the long-term development of the Mkuze River floodplain, South Africa. Geomorphology 119, 88-96.

Kadlec, J., et al. (2009) Morava River floodplain development during the last millennium, Strážnické Pomoraví, Czech Republic. The Holocene 19, 499-509.

Knox J.C. (2006) Floodplain sedimentation in the Upper Mississippi Valley: Natural versus human accelerated. Geomorphology 79, 286-310.

Lair, G.J., et al. (2009) Dating of soil layers in a young floodplain using iron oxide crystallinity. Quaternary Geochronology 4, $260-266$.

Leslie, C. \& Hancock, G.J. (2008) Estimating the date corresponding to the horizon of the first detection of ${ }^{137} \mathrm{Cs}$ and ${ }^{239+240} \mathrm{Pu}$ in sediment cores. J. Environ. Radioactivity 99, 483-490.

Lokas, E., et al. (2010) Simultaneous use of trace metals, ${ }^{210} \mathrm{~Pb}$ and ${ }^{137} \mathrm{Cs}$ in floodplain sediments of a lowland river as indicators of anthropogenic impacts. Water Air Soil Pollut. 207, 57-71.

Lu, X.X. \& Higgitt D.L. (2001) Sediment delivery to the Three Gorges 2: Local response. Geomorphology 41, $157-169$.

Macklin, M.G., et al. (2006) A geomorphological approach to the management of rivers contaminated by metal mining. Geomorphology 79, 423-447.

Mizugaki, S., Nakamura F. \& Araya T. (2006) Using dendrogeomorphology and ${ }^{137} \mathrm{Cs}$ and ${ }^{210} \mathrm{~Pb}$ radiochronology to estimate recent changes in sedimentation rates in Kushiro Mire, Northern Japan, resulting from land use change and river channelization. Catena 68, 25-40.

Owens, P.N., Walling, D.E. \& Leeks, G.J.L. (1999) Deposition and storage of fine-grained sediment within the main channel system of the River Tweed, Scotland. Earth Surf. Proc. Landforms 24, 1061-1076.

Ritchie, J.C., et al. (2004) Sediment deposition in the flood plain of Stemple Creek Watershed, northern California. Geomorphology 61, 347-360.

Saint-Laurent, D., et al. (2010) Floodplain sedimentation rates, soil properties and recent flood history in southern Québec. Global and Planetary Change, 70, 76-91.

Terry, J.P., Garimella, S. \& Kostaschuk, R.A. (2002) Rates of floodplain accretion in a tropical island river system impacted by cyclones and large floods. Geomorphology 42, 171-182.

Terry, J.P., Kostaschuk, R.A. \& Garimella, S. (2006) Sediment deposition rate in the Falefa River basin, Upolu Island, Samoa. J Environ. Radioactivity 86, 45-63.

Terry, J.P., Lal, R. \& Garimella, S. (2011) Assessing the utility of ${ }^{210} \mathrm{~Pb}$ geochronology for estimating sediment accumulation rates on river floodplains in Fiji. Singapore J. Trop. Geogr. 32, 102-14.

Walling, D. E. \& He, Q. (1997) Use of fallout ${ }^{137} \mathrm{Cs}$ in investigations of overbank sediment deposition on river floodplains. Catena 29, 263-82.

Walling, D. E. \& He, Q. (1998) The spatial variability of overbank sedimentation on river floodplains. Geomorphology 24, $209-223$.

Walling, D.E., et al. (2003) Storage of sediment-associated nutrients and contaminants in river channel and floodplain systems. Appl. Geochem. 18, 195-220.

Walling, D.E., Owens, P.N. \& Leeks, G.J.L. (1998) The role of channel and floodplain storage in the suspended sediment budget of the River Ouse, Yorkshire, UK. Geomorphology 22, 225-242.

Yan P., et al. (2002) ${ }^{137}$ Cs dating of lacustrine sediments and human impacts on Dalian Lake, Qinghai Province, China. Catena 47, 91-99. 